\title{
SELECTING FOR COUPLING-PHASE RECOMBINATION BETWEEN POTYVIRUS RESISTANCE AND WHITE ENDOSPERM COLOUR IN MAIZE PREFERRED BY FARMERS IN SUB-SAHARAN AFRICA (SSA)
}

Victoria B. Bulegeya ${ }^{1}$, Mark W. Jones², Tryphone G. Muhamba ${ }^{3}$, Biswanath Das ${ }^{4}$, Peter R. Thomison ${ }^{5}$, David M. Francis ${ }^{6}$, Margaret. G. Redinbaugh ${ }^{7}$

1 Tanzania Agriculture Research Institute (TARI - Dakawa), Tanzania

2 United States Department of Agriculture-Agricultural Research Service (USDA-ARS), Corn, Wheat and Soybean Research, USA

3 Department of Crop Science and Horticulture, Sokoine University of Agriculture (SUA),

Tanzania

4 International Maize and Wheat Improvement Center (CIMMYT), Kenya

5 Department of Horticulture and Crop Science, The Ohio State University, USA

6 Department of Horticulture and Crop Science, The Ohio State University-Ohio

Agriculture Research and Development Center (OARDC), USA

7 USDA-ARS, Corn, Wheat and Soybean Research, Department of Plant Pathology,

The Ohio State University, USA

Maize lethal necrosis (MLN) disease caused by a combined infection of Maize chlorotic mottle virus (MCMV) and any cereal infecting potyvirus is a threat to food security in Sub-Saharan Africa (SSA). Resistance to potyvirus has been extensively studied and Mdm1 gene for potyvirus resistance on chromosome 6 of maize is linked to $Y 1$ gene for maize endosperm colour. This study is aimed at selecting for coupling-phase recombination of potyvirus resistance and white endosperm colour. White susceptible maize lines CML333 and CML277 were crossed with a yellow resistant line, Pa405, to produce F1 and F2 progenies. Progenies were screened using molecular markers to recover 22 white endosperm recombinants. 22 selections were advanced to F3 recombinant families, and 10 were assayed for their responses to Maize dwarf mosaic virus (MDMV) and Sugarcane mosaic virus (SCMV). Four families segregated for SCMV resistance, selection of homozygous recombinants within these families will provide lines appropriate for improving lines with resistance to SCMV and MLN resistance in SSA.

KEY WORDS: MAIZE LETHAL NECROSIS (MLN), WHITE MAIZE, POTYVIRUS RESISTANCE, GENETIC RECOMBINATION, SUB-SAHARAN AFRICA. 


\section{Introduction}

Maize is a very important staple crop in Sub-Saharan Africa (SSA) grown on over 27 million hectares and accounting for $30 \%$ of cereals produced, with the following regional distribution as a percentage of total cereals: West Africa, I9\%; Central Africa, 6r\%; East Africa, 29\%; and Southern Africa, 65\% (FAO, 2010). Maize alone accounts for $30 \%$ of total calorie intake in Southern Africa (FAO, 20I0). White maize is exclusively preferred for human consumption in Africa, due to historical reasons and palatability preferences. Yellow maize is equated with animal feed and has a negative association with food aid during difficult historical periods (Smale \& Jayne, 2003). In Tanzania, maize constitutes a major part of all meals prepared by over 49 million people. Over $70 \%$ of maize is produced as a staple food in the form of white maize flower, which makes up the main source of energy (USAID, 20I0). Annual per capita consumption is $73 \mathrm{Kg}$ of maize per person per year (USDA GAIN report, 20I7).

Because maize is the main source of food for people in SSA, Maize lethal necrosis (MLN) reported in the region since 2012 is a threat to food security and the nutritional requirements of people in SSA (Mahuku et al., 2015: 956-965). MLN is caused by a combined infection of Maize chlorotic mottle virus (MCMV) and any maize infecting virus in the potyvirus group such as Wheat streak mosaic virus (WSMV), Maize dwarf mosaic virus (MDMV) and Sugarcane mosaic virus (SCMV) (Niblett \& Claflin, I978: I5-I9; Uyemoto et al., I980: 99-I00). In East Africa the primary cause of the disease is a co-infection with Maize chlorotic mottle virus and Sugarcane mosaic virus (Wangai et al., 2012: 205-212; Adams et al., 20I4: 2044- 0588; Lukanda et al., 2014 30-35; Mahuku et al., 2015: 956965). Sources of resistance to MLN have not been described, although sources of resistance to potyvirus have been studied and identified. Genetic studies have found potyvirus resistance genes clustered on maize chromosomes 3, 6 and io (Jones et al., 2007: I85-I9o; Stewart et al., 20I3: 289-297 \& Zambrano et al., 20I4: 867-880). Two dominant genes Scmu1 and Scmu2 are known to confer complete expression of resistance to SCMV (Lubberstedt et al., 2006: 352-356). Scmv1 is located on the short arm of chromosome 6 and Scmu2 is located near the centromere of chromosome 3 (Melchinger et al., I998: II5I-II6I; Xia et al., I999: 660-667; Zhang et al., 2003: 307-3I2). The Mdm1 gene for controlling MDMV is also located on the short arm of chromosome 6 near the nucleolar organiser region (nor) (Simcox et al, I995: 34I-346). This locus also contains Wsm1, which confers resistance to WSMV (Jones et al, 2007: I85-I90; Xia et al, I999: 660-667; $\mathrm{Xu}$ et al, I999: 574-58I). The genes segregate in a dominant fashion in both US (Louie et al., I991:I4-I8; McMullen et al., I994: 708-7I2; Jones et al., 2007: I85-I90) and European germplasm (Kuntze et al., I997: 499-50I; Melchinger et al., I998: II5I-II6I). Resistance to WSMV is conferred by QTL on chromosome 3, 6 and ro (McMullen et al., I994; Stewart et al., 2012; Zambrano et al., 2014)

One of the known sources of resistance to potyviruses, the Mdm1 locus, is linked to the endosperm colour gene (Y1) on chromosome six (6). Several studies have explored the linkage relationship between endosperm colour and potyvirus resistance in maize (Scott, I989: I478-I480; McMullen and Louie, I989: 309-3I4; Simcox, I995: 34I-346). The locus controlling endosperm colour is located $-5 \mathrm{cM}$ away from the locus controlling potyvi- 
rus resistance on the short arm of chromosome 6 (McMullen and Louie, I989: 309-314). Given that both genes are dominant, maize lines with potyvirus resistance tend to have yellow endosperm and lines with white endosperm have little or no potyvirus resistance. Despite linkage relationships, crossing over between a recessive form of $y 1$ and the dominant Mdm1 gene can be identified (Scott, I989: I478-I480; Simcox et al., I995: 34I-346). The Y1 locus is located on the long arm of chromosome 6 of maize. The locus is estimated to be 3,73I base pairs (MGDB, 2015; http://archive.maizegdb.org; URL verified 25/06/20I5) and encodes phytoene synthetase I (PHYI). The locus is the first committed step of the carotenoid biosynthesis pathway and determines endosperm colour in maize (Buckner et al., I990: 867-876). There are several known alleles of Y1 named on the basis of their phenotype. The dominant allele, $\mathrm{Y}_{1}$, produces yellow endosperm and green leaves, a recessive allele $y 1$ produces white to pale-yellow endosperm and green leaves and a pastel $y 1$ allele which produces a white to pale yellow endosperm and pale green leaves. The pale green leaves of a pastel allele are due to reduced carotenoid level in the seedling leaves resulting in photo-oxidation of chlorophyll. At the molecular level there are many allelic variants described based on DNA sequence (Buckner et al., I996: 479488).

In efforts to control MLN, it may be important to select for potyvirus resistance in white kernelled maize preferred by farmers and consumers in East Africa. Selecting for Mdm1 resistance in a recessive $y_{1}$ background would be one approach to combine potyvirus resistance and food-grade colour. Identifying recombinants that bring resistance and white endosperm into the coupling-phase will be a step forward to controlling MLN disease. The objective of the study was to select for coupling-phase genetic linkage between the Mdm1 locus and white endosperm colour to create breeding materials that can be used to develop resistant food-grade maize.

\section{Materials and methods}

\section{Germplasm materials and DNA extraction}

Germplasm was derived from a cross of a potyvirus resistance yellow line $\mathrm{Pa} 405$ and 2 potyvirus susceptible white CIMMYT lines, CML333 and CML277. Fi hybrids were selfpollinated during the winter of 20I5. Seed from self-pollinated Fi plants were separated based on kernel colour and only white seeds (genotype y1y1y1) were planted. These 900 F2 progeny were evaluated for a recombination event linking a potyvirus resistance and a recessive form of $y 1$ by using molecular markers.

DNA was extracted using a modified cetyl trimethylammonium bromide (CTAB) extraction protocol (Doyle \& Dickson, I987). Tissue ( $0.2 \mathrm{~g}$ ) was collected from young leaves of I-2 weeks old greenhouse plants into I.2 $\mathrm{ml}$ tubes (8-strip polypropylene cluster tubes, Costar, Corning, Inc.). Tubes were racked in a 96 wells format, and $4 \mathrm{~mm}$ metal balls were added to each tube. An extraction buffer I50 $\mu$ l containing $0.35 \mathrm{M}$ sorbitol, O.I M Tris and $0.005 \mathrm{M}$ EDTA was added to each well. Then $\mathrm{I} 50 \mu \mathrm{l}$ of the a lysis buffer with $0.2 \mathrm{M}$ Tris, $0.005 \mathrm{M}$ EDTA, $2.0 \mathrm{M} \mathrm{NaCl}$ and $2 \% \mathrm{CTAB}$ was added followed by a $60 \mu \mathrm{l}$ $5 \%$ sarkosyl. The tubes were then shaken using a GenoGrinder (BT\&C/OPS Diagnos- 
tics, Bridgewater, NJ) for 3 minutes at 300 strokes per minute. The samples were incubated for 20 minutes at $65^{\circ} \mathrm{C}$, then cooled, and mixed with $350 \mu \mathrm{l}$ of chloroform with isoamyl alcohol (24:I). The tubes were inverted 3-5 times then centrifuged at $3000 \mathrm{x} \mathrm{g}$ for Io minutes. The upper aqueous phase was then removed and transferred to a 96 -well plate. Then, $\mathrm{I} 25 \mu \mathrm{l}$ of isopropanol was added and the mixture was centrifuged for $15-20$ minutes for DNA precipitation. The pellets were air dried for 20 to 30 minutes and $200 \mu \mathrm{l}$ of TE buffer (Io mM Tris-HCl, pH 7.5 to 8.o, and o.I mM EDTA) was added to re-suspend the DNA. DNA was stored at $4^{\circ} \mathrm{C}$.

\section{Polymerase chain reaction (PCR)}

Extracted DNA was used as a template for polymerase chain reaction (PCR) to amplify allele differences among F2 plants. Primers amplifying polymorphic markers on chromosome six (6) bin 6.or were used to identify recombinant plants from F2 population. Short sequence repeat (SSR) primers for umc2515 (forward primer GCTAGGAGGCGCTAAATCGAG, reverse TCGATCTGCACAGATGAGTCAGTA) and bnlg1600 (forward primer TAGGCATGCATTGTCCATTG reverse primer CGATCAGTGCGTGGAGAGTA) detected polymorphism between the two parents. Markers and gene order are described in Table I. The PCR mix contained $4 \mu \mathrm{l}$ DNA, o.2 $\mu$ l each forward and reverse primer (IOO mM), $0.8 \mu \mathrm{l} 0.05 \mathrm{mM}$ dNTPs, $0.4 \mu \mathrm{l} \mathrm{Taq}$ polymerase and $\mathrm{I} 2.4 \mu \mathrm{l}$ of PCR buffer solution (IOo mM Tris- $\mathrm{HCl}, \mathrm{pH} 9$ at $25^{\circ} \mathrm{C}, 500 \mathrm{mM} \mathrm{KCl}$ and $\mathrm{I} 5 \mathrm{mM} \mathrm{MgCl}_{2}$ ). PCR reactions consisted of an initial denaturation at $95^{\circ} \mathrm{C}$ for 3 minutes, followed by 40 cycles of 60 second denaturing at $95^{\circ} \mathrm{C}$, annealing at $56^{\circ} \mathrm{C}$ for 45 seconds, extension at $72^{\circ} \mathrm{C}$ for 30 seconds, and a final extension at $72^{\circ} \mathrm{C}$ for Io minutes.

\section{Gel electrophoresis}

PCR products were separated on $3 \%$ agarose gels in IX TBE ( $0.744 \mathrm{~g}$ of EDTA, Io. $8 \mathrm{~g}$ Tris base, $5.5 \mathrm{~g}$ boric acid and $\mathrm{ddH}_{2} \mathrm{O}$ to $\mathrm{I} \mathrm{L}$ ). The results were scored for the recombination of Mdm1-linked markers and the y1 allele.

\section{Phenotypic evaluation}

Selected recombinants were self-pollinated and $\mathrm{F}_{3}$ families with white kernels and segregating for markers linked to Mdm1 were assayed for MCMV and SCMV resistance. Recombinants with coupling-phase allele combination of $y_{1}$ and $M d m 1$ resistance alleles were expected to segregate for resistance. Progenies were inoculated with MDMV and SCMV through rub inoculation separately and grown in the greenhouse. Disease incidence data was collected 7 days post inoculation at an interval of 2 days.

\section{Results}

Selection for recombinants using kernel colour

F2 progenies were generated from Fi seeds selected based on kernel colour. Since both $\mathrm{Y}_{1}$ and Mdm1 are dominant, initial selection was based on white kernel colour. $\mathrm{Y}_{1}$ is expressed in the endosperm, and inheritance was expected to follow a triploid pattern with 
YiYıYı, YiYıyı, Yıугуг, and yryıy kernels in an expected ratio of I:3:3:I. Heterozygous classes were not easily distinguished and therefore the expected segregation was 7:I, yellow: white. The chi-square test showed that progeny from the CML277 cross segregated as expected with a failure to reject 7:I segregation ( $\mathrm{P}=0.43$ ). In the CML333 cross, there were more white kernels progeny than expected; hence segregation did not fit the expected 7:I $(\mathrm{P}<0.05)$. A possible explanation for this result would be that yryiYI endosperm seeds were counted as y1y1y1. A total of $900 y_{1}$ ( $\left.y_{1} y_{1} y_{1}\right)$ seeds were selected: 500 from CML333 and 400 from CML277 and were planted to generate F2 seedlings which were screened using molecular markers.

\section{Selection for recombinants using SSR markers}

PCR analysis was performed on each selected F2 progeny to test for the presence or absence of recombination between $y_{1}$ and markers linked to Mdm1. The marker bnlg16oo was amplified at I9o bp for CML333 and CML277 parents and 210 bp for Pa405 parents. F2 progenies with either a 210 bp amplicon or heterozygous for 2 Io and I9o bp amplicons were selected (Figure 4.I). Marker umc2515 amplified a I50 bp band from CML333 and CML277 and I6o bp amplicon from Pa405. No F2 plants homozygous for the desired Pa405 alleles were identified, but 22 plants heterozygous for one or both markers were selected (Table 2). Twenty-two selected plants were transplanted into bigger pots and grown in a greenhouse and self-pollinated to generate $\mathrm{F}_{3}$ seeds, which were assayed for disease resistance (Table 2).

\section{Response of selected recombinants to infection with MDMV and SCMV}

Seedlings from 25 kernels for each of six $\mathrm{F}_{3}$ recombinant plants were assayed for their responses to inoculation with MDMV and SCMV. Of the six selected recombinant families, two were derived from CML333 and four from CML277. There is variation to response of F3 progenies to inoculation with MDMV and SCMV. No seedlings developed symptoms after inoculation with MDMV. Control plants CML333 and CML277 also failed to develop MDMV symptoms suggesting that these lines already possessed resistance from another locus. This virus was therefore not useful to verify recombinants with Mdm1.

Seedlings derived from two $\mathrm{F}_{3}$ families were completely susceptible to SCMV, suggesting that these families derived from an F2 plant where the recombination event detected based on the marker did not include the resistance gene. Four families showed segregation for resistance to SCMV. These four families were evenly divided between CML333 and CML277 parentage, and selection of homozygotes for the recombinant chromosome will provide $y 1$ (white) - Mdm1 (resistant) coupling-phase material for future breeding efforts.

\section{Discussion}

Conventional breeding can be time consuming and resource intensive. The use of molecular markers in plant breeding has been a useful tool for selection in conjunction with increased breeding cycles per unit time. Markers can also minimize resources required 
for selection relative to conventional breeding. The selection of recombinants is one example of where marker assisted selection (MAS) can provide a resource benefit relative to conventional breeding. Resistance to MDMV and SCMV in line Pa405 is conferred by a dominant gene linked to a dominant gene for yellow endosperm (McMullen \& Louie, I989: 309-3I4). Lines CML333 and CML277 have white endosperms conferred by a recessive $y 1$ gene and lack resistance to MDMV/SCMV conferred Mdm1. This study aimed at breaking the linkage between the dominant $M d m_{1}$ and $Y_{1}$ in order to recover recombinant plants with a dominant $M d m 1$ and a recessive $y 1$.

Various studies suggest the possibility of detecting desirable recombinants on chromosome 6 (Simcox, I995: 34I-346; McMullen and Louie, I989: 309-3I4). The loci are approximately 3.3 cM apart (McMullen and Louie, I989: 309-3I4) indicating a $1.65 \%$ probability of recovering recombinants with a dominant $M d m 1$ and a recessive $y 1$ from a cross of yellow endosperm ( $\left.\mathrm{Y}_{1} / \mathrm{Mdm} 1\right)$ to white endosperm ( $\left.\mathrm{y}_{1} / \mathrm{mdm}_{1}\right)$. In this work, the recovery of 22 putative recombinants out of 900 progeny indicated a $2.4 \%$ recovery and a recombination fraction of $4.8 \mathrm{cM}$. For this study two flanking markers were used to ensure a successful selection of the recombinant plants. Marker umc2515 and marker bnlg160o flank the Mdm1 locus and the two markers distal to the $Y_{1}$ locus. Detection of recombinants with markers does not guarantee recombination between $\mathrm{Y}_{1}$ and Mdm1 due to the possibility that the recombination event was distal to MdmI relative to YI, or due to double recombinants.

When recombinant $\mathrm{F}_{3}$ families were assayed for potyvirus resistance with SCMV and MDMV, all progenies were resistant to MDMV despite the expectation of segregation in the families. This result is explained by the fact that CML333 and CML277 were also resistant, suggesting that genes other than $M d m 1$ are contributing to resistance in these populations. Results also indicate that four of 6 progenies were segregating for resistance to SCMV, suggesting that this test was useful for phenotypic verification of coupling-phase recombination between $M d m 1$ and $y_{1}$. Two of the families were completely susceptible to SCMV, suggesting that these recombinants failed to retain the resistant allele.

The results suggest that up to $2 / 3$ of the recombinants detected with molecular markers established the desired coupling-phase. The four families identified based on phenotypic evaluation are equally divided between CML 333 and CML 277 genetic backgrounds and selection of homozygotes for the recombinant chromosome will provide yI - MdmI coupling-phase materials for future breeding efforts.

The research was able to successfully move the Mdm1 locus from yellow endosperm maize to white endosperm maize through genetic recombination. The selected recombinants will need to undergo another breeding cycle to fix the Mdm1 allele to be available for use in breeding programs. The results are expected to be useful for breeding programs in Africa where MLN is a threat to maize production and white maize is preferred for food (Mahuku et al., 2015: 956-965). The majority of tropical maize lines currently showing resistance or tolerance to MLN are yellow (Gowda et al., 2015: I957-I968). Moving potyvirus resistance to a white endosperm background is steps towards ensuring a food secure Sub-Saharan Africa with preferred maize food grade maize. 


\section{Acknowledgement}

Our deep appreciation goes to the USAID feed the future program under iAGRI-Tanzania for funding our research at Ohio State University and the Borlaug LEAP fellowship for the additional funding of laboratory activities. We would like to thank the USDA, ARS Corn, Soybean and Wheat Quality Research Unit (CSWQRU) at Selby Hall and Dr. Francis' lab at Williams's Hall, both at OARDC, Wooster, Ohio for supporting most of the lab, greenhouse and field activities.

\begin{tabular}{l|r|l|l}
\hline Locus & Position (cM) & Distance (bp) & Function \\
\hline umc2515 & 68.9 & $9499043-9499063$ & Marker \\
\hline Mdm1 & 69.1 & $9,491,573-14,940,074$ & Gene (resistance) \\
\hline bnlg1600 & 75.8 & $29,798,872-29,798,891$ & Marker \\
\hline Y1 & 120.5 & $82,017,148-82,020,879$ & Gene (endosperm) \\
\hline
\end{tabular}

Table 1. Marker location for umc2515 and bnlg1600 on chromosome 6 of maize from the maize genome database (www.maizegdb.com)

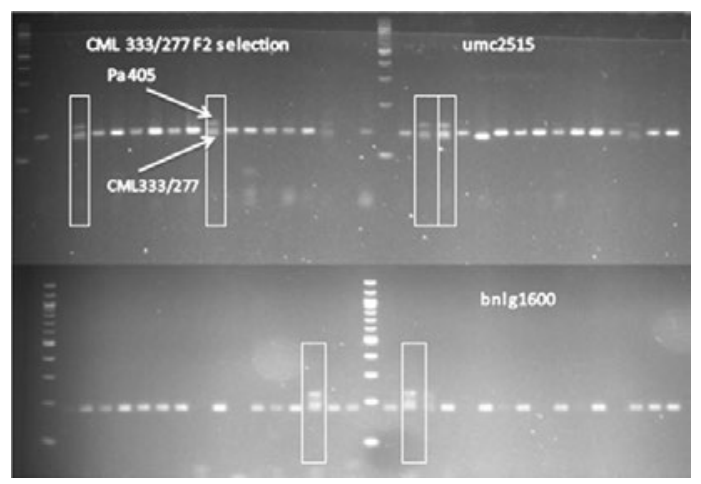

Figure 1. Gel electrophoresis picture of DNA samples from selected F2 progenies displaying recombinant plants using marker umc2515 (top) and marker bnlg1600 (bottom). All progeny are y 1 y 1 y 1 , and heterozygous marker patterns therefore demonstrate the occurrence of a recombination. 


\begin{tabular}{|c|c|c|c|c|c|c|}
\hline & F3 families ${ }^{c}$ & $\begin{array}{l}\text { umc2515 } \\
\text { genotype }\end{array}$ & $\begin{array}{l}\text { bnlg1600 } \\
\text { genotype }\end{array}$ & $\mathrm{Y} 1^{\mathrm{e}}$ & MDMV & SCMV \\
\hline 1 & CML333 & $\mathrm{Aa}$ & $\mathrm{Aa}$ & $y 1 y 1 y 1$ & N.Df & N.D \\
\hline 2 & CML333 & $\mathrm{Aa}$ & $\mathrm{Aa}$ & y1y1y1 & N.D & N.D \\
\hline 3 & CML333 & $\mathrm{Aa}$ & $\mathrm{Aa}$ & $y 1 y 1 y 1$ & N.D & N.D \\
\hline 4 & CML333 & $\mathrm{Aa}$ & AA & y1y1y1 & N.D & N.D \\
\hline 5 & CML333 & $\mathrm{Aa}$ & $\mathrm{Aa}$ & y1y1y1 & N.D & N.D \\
\hline 6 & CML333 & $\mathrm{Aa}$ & $\mathrm{Aa}$ & y1y1y1 & N.D & N.D \\
\hline 7 & CML333 & $\mathrm{Aa}$ & $\mathrm{Aa}$ & y1y1y1 & N.D & N.D \\
\hline 8 & CML333 & $\mathrm{Aa}$ & AA & $y 1 y 1 y 1$ & N.D & N.D \\
\hline 9 & CML333 & AA & $\mathrm{Aa}$ & y1y1y1 & N.D & N.D \\
\hline 10 & CML333 & AA & $\mathrm{Aa}$ & y1y1y1 & $0 / 25$ & $1 / 25$ \\
\hline 11 & CML333 & $\mathrm{Aa}$ & $\mathrm{Aa}$ & $y 1 y 1 y 1$ & N.D & N.D \\
\hline 12 & CML333 & $\mathrm{Aa}$ & $\mathrm{Aa}$ & $y 1 y 1 y 1$ & $0 / 25$ & $3 / 25$ \\
\hline 13 & CML277 & Aa & Aa & $y 1 y 1 y 1$ & N.D & N.D \\
\hline 14 & CML277 & $\mathrm{Aa}$ & AA & y1y1y1 & N.D & N.D \\
\hline 15 & CML277 & $\mathrm{Aa}$ & $\mathrm{Aa}$ & y1y1y1 & $0 / 25$ & N.D \\
\hline 16 & CML277 & Aa & Aa & $y 1 y 1 y 1$ & $0 / 25$ & $23 / 25$ \\
\hline 17 & CML277 & $\mathrm{Aa}$ & AA & y1y1y1 & N.D & N.D \\
\hline 18 & CML277 & $\mathrm{Aa}$ & AA & y1y1y1 & N.D & N.D \\
\hline 19 & CML277 & $\mathrm{Aa}$ & AA & $y 1 y 1 y 1$ & $0 / 25$ & $3 / 25$ \\
\hline 20 & CML277 & $\mathrm{Aa}$ & AA & $y 1 y 1 y 1$ & $0 / 25$ & $3 / 25$ \\
\hline 21 & CML277 & $\mathrm{Aa}$ & AA & y1y1y1 & N.D & N.D \\
\hline 22 & CML277 & AA & Aa & y1y1y1 & $0 / 25$ & $13 / 13$ \\
\hline 23 & CML333a & AA & AA & $y 1 y 1 y 1$ & $0 / 12$ & $6 / 12$ \\
\hline 24 & CML277ª & AA & AA & y1y1y1 & $0 / 11$ & $8 / 11$ \\
\hline 25 & $\mathrm{~Pa} 405^{\mathrm{b}}$ & aa & $\mathrm{Aa}$ & $y 1 y 1 y 1$ & $0 / 12$ & $0 / 12$ \\
\hline
\end{tabular}

Allele genotypes form marker umc2515 and bnlg1600:

AA: Homozygous CML333/CML277, Aa: Heterozygous CML333/CML277 and aa: Homozygous Pa405

a Parent: CML333 and CML277 susceptible parents for potyvirus resistance.

bParent: Pa405 a resistant parent

'F3 recombinants: Selected F3 plants from a population of CML333/CML277 X Pa405 using markers

dumc 2515 and bnlg1600 flanking Mdm1 locus

eY1: Endosperm color allele

${ }^{\mathrm{f} N}$.D: Not done

Table 2. Selected recombinants with coupling phase between mdm1 loci and y1 loci 


\section{References}

Adams, I. P., Harju, V.A., Hodges, T., Hany, U., Skelton, A., Rai, S.\& Ngaboyisonga, C. (2014). First report of maize lethal necrosis disease in Rwanda. New Disease Report, 29(22), 2044-588.

Buckner B., San Miguel P., Janick-Buckner D. \& Ben- netzen J. (1996). The yl gene of maize codes for phy- toene synthase. Genetics, 143, 479-488.

De Groote, H., Oloo, F., Tongruksawattana, S., \& Das, B. (2016). Community-survey based assessment of the geographic distribution and impact of maize lethal necrosis (MLN) disease in Kenya. Crop Protection, 82, 30-35.

Dussle, C., Quint, M., Xu, M., Melchinger, A., \& Lübberstedt, T. (2002). Conversion of AFLP fragments tightly linked to SCMV resistance genes Scmvi and Scmv2 into simple PCR-based markers. Theoretical and Applied Genetics, 105(8), II90-II95.

FAOSTAT (2010). Statistical databases and data-sets of the Food and Agriculture Organization of 508 the United Nations. Food and Agriculture Organization of the United Nations. http://faostat.fao. orgdefault.aspx. Accessed April, 2014.

Gowda, M., Das, B., Makumbi, D., Babu, R., Semagn, K., Mahuku, G., Babu, R., Semagn, K., Olsen, M. S., Bright, J. M., Beyene, Y \& Prasanna, B. M. (2015). Genome-wide association and genomic prediction of resistance to maize lethal necrosis disease in tropical maize germplasm. Theoretical and Applied Genetics, 128(ro), 1957-rg68.

Jones, M. W., Redinbaugh, M. G., \& Louie, R. (2007). The MdmI locus and maize resistance to Maize dwarf mosaic virus. Plant Disease, 9I: I85-190.

Kuntze, L., Fuchs, E., Grüntzig, M., Schulz, B., Klein, D., \& Melchinger, A. E. (1997). Resistance of early-maturing European maize germplasm to sugarcane mosaic virus (SCMV) and maize dwarf mosaic virus (MDMV). Plant Breeding, 116(5), 499-501.

Li, Z., Chen, J., Han, L., Wen, J., Chen, G., Li, H., ... \& Yan, J. (20r6). Association mapping resolving the major loci Scmv2 conferring resistance to sugarcane mosaic virus in maize. European Journal of Plant Pathology, I45(2), 385-391.

Liu, X. H., Tan, Z. B., \& Rong, T. Z. (2009). Molecular mapping of a major QTL conferring resistance to SCMV based on immortal RIL population in maize. Euphytica, 167(2), 229-235.

Louie, R., \& Anderson, R. J. (1993). Evaluation of Maize chlorotic dwarf virus resistance in maize with multiple inoculations by Graminella nigrifrons (Homoptera, Cicadellidae).

Journal of Economic Entomology, 86, 1579-1583.

Lubberstedt, T., Ingvardsen, C., Melchinger, A.E., Xing, Y., Salomon \& R., Redinbaugh, M.G. (2006) Two chromosome segments confer multiple potyvirus resistance in maize. Plant Breeding, I25:352-356

Lukanda, M., Owati, A., Ogunsanya, P., Valimunzigha, K., Katsongo, K., Ndemere, H., \& Kumar, P. L. (20I6). First Report of Maize chlorotic mottle virus Infecting Maize in the Democratic Republic of the Congo. Crop Protection, 82, 30-35.

Mahuku, G., Lockhart, B. E., Wanjala. B., Jones, M. W., Kimunyer, J. N., Stewart, L. S., Cassone, B. J., Sevgan, S., Nyasani, J. O., Kusia, E., Kumar, L.P., Niblett, C. L., Kiggundu, A., Asea, G., Pappu, H.R., Wangai, A., Prasanna, B.M. \& Redinbaugh, M.G. (2015). Maize lethal necrosis (MLN), an emerging threat to maize-based food I security in Sub-Saharan Africa. Phytopathology, I05(7): 956 -965 .

McMullen, M. D., \& Louie, R. (I989). The linkage of molecular markers to a gene controlling the symptom response in maize to maize dwarf mosaic virus. Molecular Plant-Microbe Interactions, 2(6), 309-3I4.

McMullen, M. D., \& Louie, R. (I99I). Identification of a gene for resistance to wheat streak mosaic virus in maize. Phytopathology, 81(6), 624-627.

McMullen, M. D., Jones, M. W., Simcox, K. D., and Louie, R. (1994). Three genetic loci control resistance to wheat streak mosaic virus in the maize inbred Pa405. Molecular Plant-Microbe Interaction, 7:708-712. 
Melchinger, A. E., Kuntze, L., Gumber, R. K., Lübberstedt, T., \& Fuchs, E. (1998). Genetic basis of resistance to sugarcane mosaic virus in European maize germplasm. Theoretical and Applied Genetics, 96(8), II5I-II6I.

Niblett, C. L., \& Claflin, L. E. (1978). Corn lethal necrosis-a new virus disease of corn in Kansas. Plant Disease Reporter, 62(I), I5-I9.

Quint, M., Mihaljevic, R., Dussle, C.,Xu, M., Melchinger, A., \& Lübberstedt, T. (2002). Development of RGA-CAPS markers and genetic mapping of candidate genes for sugarcane mosaic virus resistance in maize. Theoretical and Applied Genetics, 105(2-3), 355-363.

Redinbaugh, M. G., \& Pratt, R. C. (2008). Virus resistance. In S. Hake, \& J. L. Bennetzen (Eds.), Handbook of maize: Its biology. pp, 255-270. New York: Springer-Verlag.

Scott, G. E. (1989). Linkage between maize dwarf mosaic virus resistance and endosperm colour in maize. Crop Science, $29(6)$, I478-I480.

Simcox, K. D., McMullen, M. D., \& Louie, R. (I995). Co-segregation of the maize dwarf mosaic virus resistance gene, MdmI, with the nucleolus organizer region in maize. Theoretical and Applied Genetics, 90(3-4), 34I-346.

Smale, M., \& Jayne, T. (2003). Maize in Eastern and Southern Africa: "seeds" of success in retrospect. Environment and Production Technology Division, International Food Policy Research Institute. 2033 K Street, N.W. Washington, D.C. 20006 U.S.A.

Stewart, L. R., Haque, M. A., Jones, M. W., \& Redinbaugh, M. G. (2013). Response of maize (Zea mays L.) lines carrying Wsm1, Wsm2, and Wsm 3 to the potyviruses Johnsongrass mosaic virus and Sorghum mosaic virus. Molecular Breeding, 31(2), 289-297.

USDA GAIN REPORT (2017). Tanzania Corn Wheat and Rice. Retrieved from https://gain.fas.usda.gov/ Recent\%20GAIN\%20Publications/Grain\%20and\%20Feed\%20Annual_Dar\%20es\%20Salaam _ Tanzania_3-29-2017.pdf.

Uyemoto, J. K., Bockelman, D. L., \& Claflin, L. E. (I980). Severe outbreak of corn lethal necrosis disease in Kansas. Plant Disease (formerly Plant Disease Reporter), 64(I), 99-Ioo

Wangai, A. W., Redinbaugh, M. G., Kinyua, Z. M., Miano, D. W., Leley, P. K., Kasina, M., \& Jeffers, D. (2015). First report of maize chlorotic mottle virus and maize lethal necrosis in Kenya. Virology, 485, 205-212.

Wisser, R. J., Balint-Kurti, P. J., \& Nelson, R. J. (2006). The genetic architecture of disease resistance in maize: a synthesis of published studies. Phytopathology, 96(2), I20-I29.

Wu, J. Y., Ding, J. Q., Du, Y. X., Xu, Y. B., \& Zhang, X. C. (2007). Genetic analysis and molecular mapping of two dominant complementary genes determining resistance to sugarcane mosaic virus in maize. Euphytica, 156(3), 355-364.

Xia, X., Melchinger, A. E., Kuntze, L., \& Lübberstedt, T. (I999). Quantitative trait loci mapping of resistance to sugarcane mosaic virus in maize. Phytopathology, 8g(8), 66o-667.

Xing, Y., Ingvardsen, C., Salomon, R., \& Lübberstedt, T. (2006). Analysis of sugarcane mosaic virus resistance in maize in an isogenic dihybrid crossing scheme and implications for breeding potyvirus-resistant maize hybrids. Genome, 49(I0), I274-I282.

Xu, M. L., Melchinger, A. E., Xia, X. C., \& Lübberstedt, T. (1999). High-resolution mapping of loci conferring resistance to sugarcane mosaic virus in maize using RFLP, SSR, and AFLP markers. Molecular and General Genetics, 261(3), 574-58r.

Zhang, S. H., Li, X. H., Wang, Z. H., George, M. L., Jeffers, D., Wang, F. G., \& Yuan, L. X. (2003). QTL mapping for resistance to SCMV in Chinese maize germplasm. Maydica, 48(4), 307-312.

Zambrano, J. L., Jones, M. W., Brenner, E., Francis, D. M., Tomas, A., \& Redinbaugh, M. G. (2014). Genetic analysis of resistance to six virus diseases in a multiple virus-resistant maize inbred line. Theoretical and Applied Genetics, 127(4), 867-880. 